\title{
Р-Т и флюидные условия взаимодействия основных ксенолитов и плагиогранитов р-на р. Лотта Центральной зоны Лапландского гранулитового комплекса
}

\author{
Бутвина В.Г., Голунова М.А., Вирюс А.А. \\ Институт экспериментальной минералогии им. Д.С. Коржинского РАН, Черноголовка, \\ butvina@iem.ac.ru
}

Аннотация. Изучение Р-Т и флюидных условий взаимодействия основных ксенолитов (гранулитов) и плагиогранитов р-на р. Лотта Центральной зоны Лапландского гранулитового комплекса подтверждают вывод о том, что лейкократовые гранатсодержащие плагиограниты Лапландского комплекса связаны с анатексисом кондалитов в период пика метаморфизма. Предположительно образование этих магм происходило на глубинах 25-30 км. Во время восхождения гранитные магмы захватили мафические (двупироксенплагиоклазовые) ксенолиты при давлениях 6.0-6.4 кбар. Взаимодействие преимущественно водно-солевых флюидов, выделяемых магмами, с ксенолитами при охлаждении на глубинах менее 20 км (5.0-5.5 кбар) привело к их широкой амфиболизации при температурах 740-780 $\mathrm{C}$.

Ключевые слова: Лапландский гранулитовый комплекс, плагиограниты, гранулит, основные ксенолиты, Р-Т параметры, флюидные включения, амфиболизация.

Аббревиатура минералов, использованная в работе: Ab - альбит, Amph - амфибол, An - анортит, Cherm - чермакит, Срх- клинопироксен, Ed - эденит, Ilm - ильменит, Mt - магнетит, Орх- ортопироксен, Pl - плагиоклаз, Parg - паргасит, Qtz - кварц, Tre - тремолит.

\section{P-T and fluid conditions of interaction between mafic xenolithes and plagiogranites in the Lotta River Area, Lapland Granulite Belt}

\author{
Butvina V.G., Golunova M.A., Virus A.A. \\ Korzhinsky's Institute of experimental mineralogy (IEM) RAS, Chernogolovka, Moscow district, \\ butvina@iem.ac.ru
}

\begin{abstract}
Thermobarometric data and fluid inclusions data of conditions of interaction between mafic xenolithes (granulites) and plagiogranites in the Lotta river area, Lapland Granulite Belt, confirm the conclusion that leucocratic garnet-bearing plagiogranites of the Lapland complex are associated with the anatexis of country khondalites during the peak of metamorphism. The formation of these magmas occurred at depths of 25-30 km. During their ascent, granitic magmas trapped mafic (two pyroxene-plagioclase) xenoliths at pressures of 6.0-6.4 kbar. The interaction of predominantly aqueous-salt fluids produced by magmas with xenoliths during cooling at depths of less than $20 \mathrm{~km}$ (5.0-5.5 kbar) led to their widespread amphibolization at temperatures of $740-780^{\circ} \mathrm{C}$.

Key words: Lapland Granulite Belt, the River Lotta Area, plagiogranites, granulite, mafic xenolithsn, thermobarometric data, fluid inclusions, amphibolization.

Mineral and end-member abbreviations: $\mathrm{Ab}$ - albite, Amph - amphibole, An - anorthite, Cherm chermakite, Cpx- clinopyroxene, Ed - edenite, Ilm - ilmenite, Mt - magnetite, Opx- orthopyroxene, Pl - plagioclase, Parg - pargasite, Qtz - quartz, Tre - tremolite.
\end{abstract}

\section{Введение}

Гранат- и ортопироксенсодержащие тоналиты и плагиограниты северо-восточной части Лапландского гранулитового комплекса (ЛГК) занимают обширные площади в районе р. Лотта и Ловнаозера и далее на запад к северной Норвегии (Митрофанов и др., 1974; Козлов, Козлова, 1998; Mints et al., 2007; Каулина и др., 2014; Glebovitsky et al., 2001). Гранатсодержащие гранитоиды обычно приурочены к зонам развития кислых гранулитов и высокоглиноземистых пород комплекса (кондалитов), образуя с ними либо интрузивные контакты, либо постепенные переходы. Основываясь на близости химического и минерального состава гранатовых плагиогранитов и вмещающих их кондалитов ряд авторов рассматривает первые в качестве крупнозернистых разновидностей последних (Marker, 1990). Однако подавляющее большинство исследователей связывают происхождение 
гранатсодержащих гранитоидов ЛГК с анатексисом кондалитов и кислых гранулитов на пике метаморфизма (Козлов, Козлова, 1998; Mints et al., 2007, 2015; Каулина и др., 2014).

На основе гранат-биотитового равновесия для гранатсодержащих плагиогранитов района p. Лотта были оценены температуры, варьирующие от 830 до $650^{\circ} \mathrm{C}$ (Козлов, Козлова, 1998), что, безусловно, нельзя считать удовлетворительным результатом. Верхний предел этого интервала температур соответствует температурам $800-850^{\circ} \mathrm{C}$, рассчитанным по содержанию Ті в цирконах (Каулина и др., 2014). Эти температуры совпадают с параметрами метаморфизма, оцененными для пород ЛГК для указанного интервала времени. Они отражают условия частичного плавления кондалитов с образованием плагиогранитной магмы на глубинах 20-29 км (6.8-9.5 кбар). Исследования флюидного режима кристаллизации гранатсодержащих гранитоидов ЛГК нам не известны. В данной работе приведены результаты расчетов Р-Т параметров и флюидных условий равновесий минералов основных ксенолитов (гранулитов) и плагиогранитов р-на р. Лотта Центральной зоны ЛГК.

\section{Петролого-минералогическое изучение основных ксенолитов в плагиогранитах лГК}

Амфиболизированный двупироксен-плагиоклаз-кварцевый сланец ЛН-101 представляет собой породу с равномернозернистой гранобластовой структурой и массивной текстурой. Главными породообразующими минералами породы являются ортопироксен (25-30 \%), клинопироксен (10-15 \%), плагиоклаз (30-40 \%) и кварц (5-10 \%). Образец ЛН-102 представляет собой амфиболизированный двупироксен-плагиоклаз-кварцевый сланец с ксенолитом амфиболизированного габбронорита, в свою очередь секущихся кварцевой жилой (рис. 1 a,b).

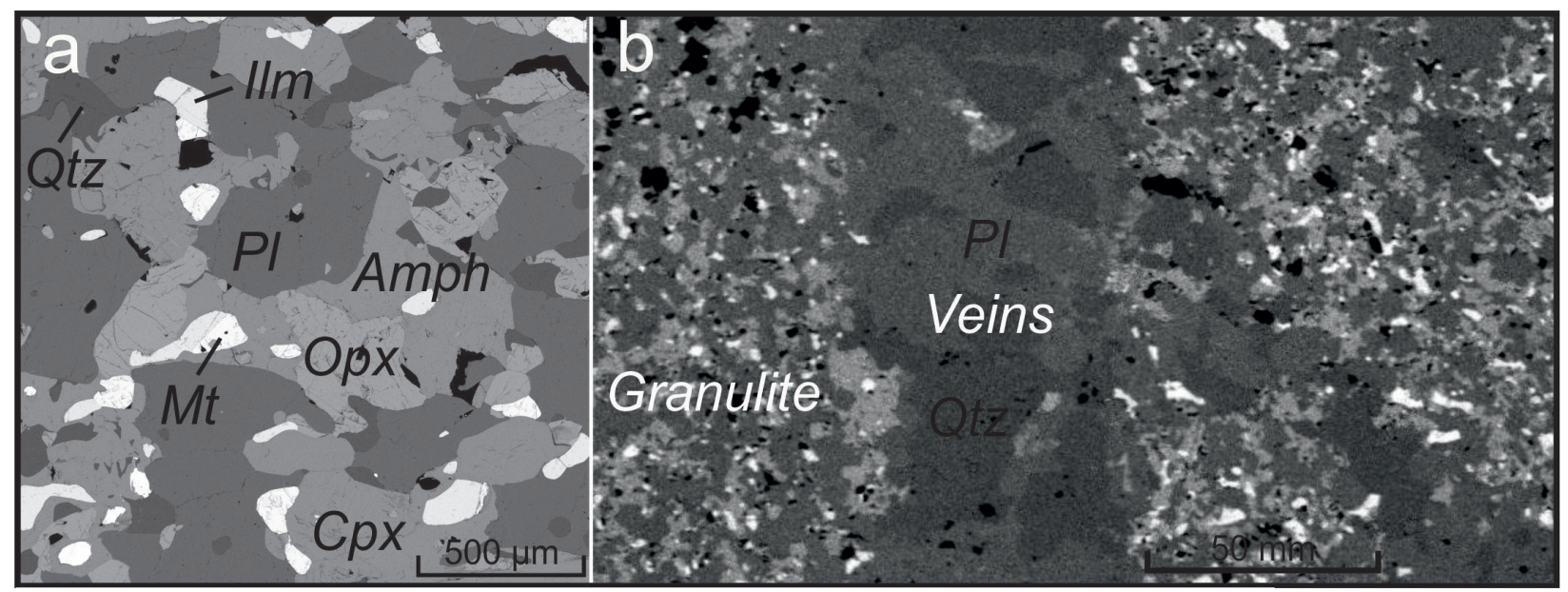

Рис. 1. Изображения минеральных парагенезисов гранулита (а) и жила плагиогрантового состава в нем (b). VEGA TS 5130ММ, ИЭМ РАН.

Fig. 1. Electron microprobe photos of mineral paragenesis of granulite (a) and veins of plagiogranite composition in it (b). VEGA TS 5130MM, IEM RAS.

Основные ксенолиты состоят из слабозонального плагиоклаза (30-40 \%; $\mathrm{An}_{47-54}$ ), низкоглиноземистых клинопироксена (10-15\%; $\mathrm{X}_{\mathrm{Mg}}=0.56-0.58,2-2.5$ мас. \% $\mathrm{Al}_{2} \mathrm{O}_{3}$ ) и ортопироксена (25-30 \%; $\mathrm{X}_{\mathrm{Mg}}=0.43-0.44,1-1.3$ мас. \% $\mathrm{Al}_{2} \mathrm{O}_{3}$ ). В зернах клинопироксена присутствуют тонкие ламели ортопироксена (рис. 2 b), а также следы распада твердого раствора ортопироксена (рис. 2 a). Акцессорные магнетит, ильменит, пирротин, халькопирит, фтор-апатит и циркон составляют 5-8 \%. Магнетит, ильменит и пирротин образуют как отдельные зерна, так и сростки друг с другом. Процесс амфиболизации в породе проявлен неравномерно с образованием вытянутых зерен размером до 2.5 мм и кайм паргасит-эденитового амфибола (рис. 3) и его срастаний с кварцем в контактах пироксенов, магнетита, ильменита и пирротина с плагиоклазом. Образование амфибола затрагивает главным образом зерна ортопироксена, который образует резорбированные реликты в амфиболе. В контактах зерен 


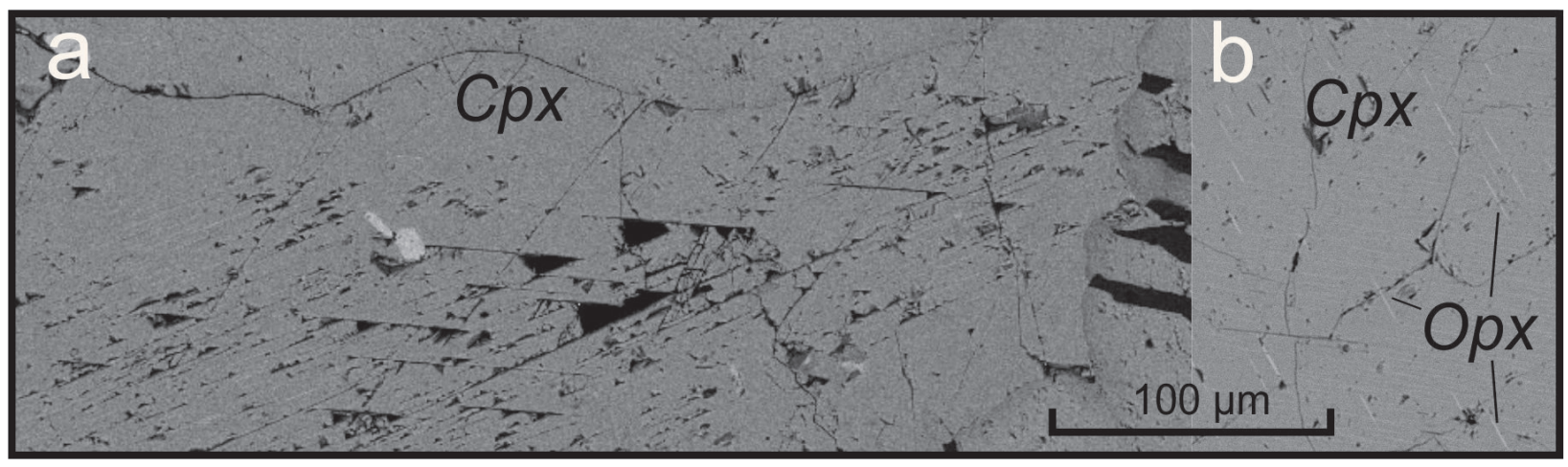

Рис. 2. Изображения следов распада твердого раствора ортопироксена в клинопироксене (а), ламелей ортопироксена в клинопироксене (b). VEGA TS 5130MМ, ИЭМ РАН.

Fig. 2. Electron microprobe photos of signs of decomposition of the solid solution of orthopyroxene in clinopyroxene (a), lamella of orthopyroxene in clinopyroxene (b). VEGA TS 5130MM, IEM RAS.

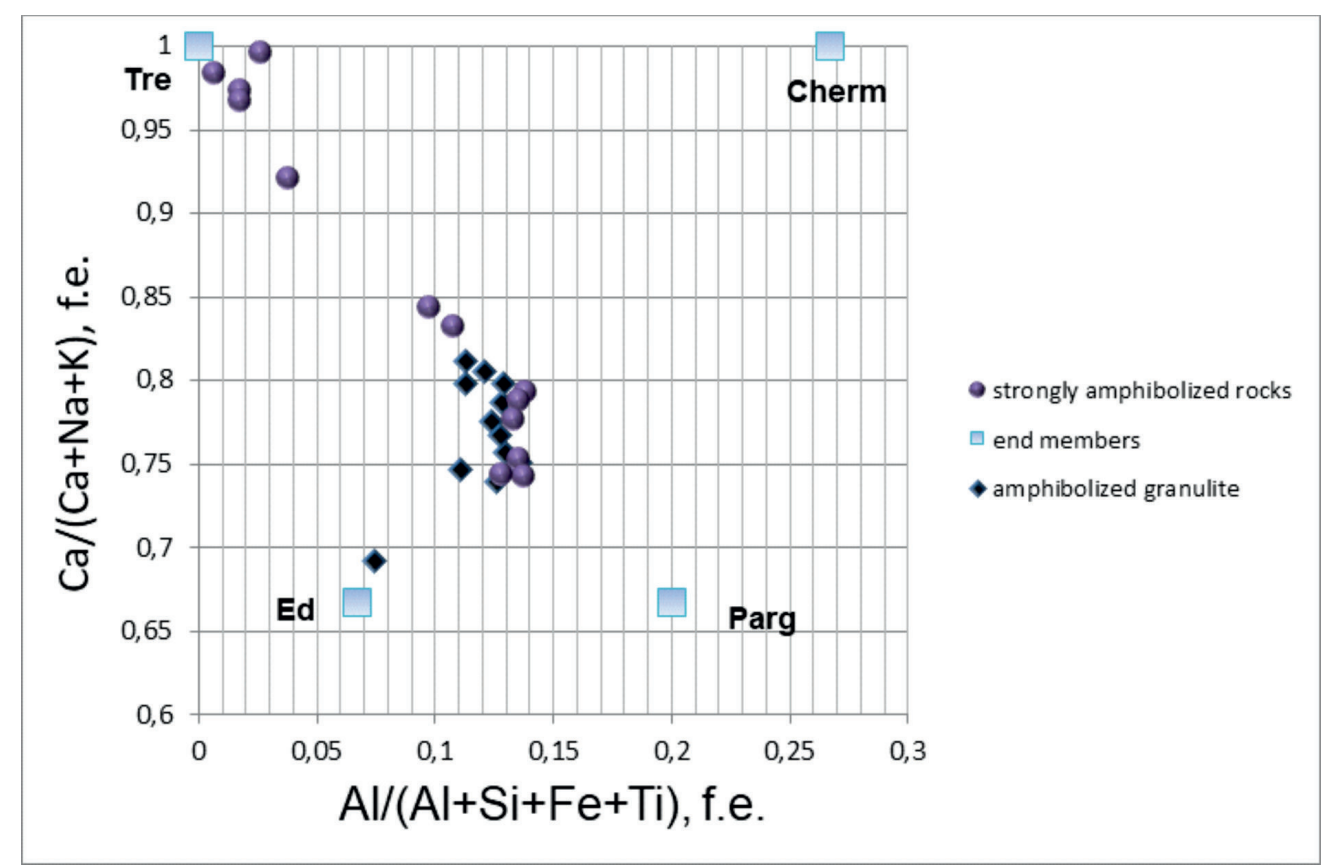

Рис. 3. Составы амфиболов основных ксенолитов в плагиогранитах р-на р. Лотта Центральной зоны Лапландского гранулитового комплекса.

Fig. 3. Compositions of amphiboles of mafic xenolithes in plagiogranites of the River Lotta Area of the Central Zone of LGB.

клинопироксена с плагиоклазом амфибол либо отсутствует, либо развит лишь в виде тонких кайм. Таким образом, процесс амфиболизации может быть представлен в виде схематической реакции

$$
\mathrm{Opx}+\mathrm{Ilm}+\mathrm{Mt}+\mathrm{Pl}=\mathrm{Amph} \pm \mathrm{Qtz},
$$

в которой клинопироксен принимает лишь опосредованное участие.

Амфиболизация местами сопровождается образованием листочков биотита и биотиткварцевых симплектитов по ортопироксену.

\section{Термобарометрическое изучение ксенолитов плагиогранитов - основных гранулитов ЛГК}

Используя программный комплекс TWQ 2.32 (Berman, 2007), по равновесию клинопироксен + ортопироксен + плагиоклаз + кварц в неамфиболизированных участках ксенолитов было оценено давление 6.0-6.4 кбар. Температуры, соответствующие этой ассоциации, составляют $800-860^{\circ} \mathrm{C}$ 
и находятся в пределах интервала температур кристаллизации плагиогранитов (Каулина и др., 2014), а также температур пика тектоно-термального этапа М2 в ЛГК (Mints et al., 2007). Амфиболплагиоклазовое равновесие (Blundy, Holland, 1990) зафиксировало температуры процесса амфиболизации ксенолитов $740-780^{\circ} \mathrm{C}$ при давлении 5.0-5.5 кбар (табл. 1).

\section{Изучение флюидных включений}

Флюидные включения в метаморфических породах были изучены в пластинках толщиной 200-300 мкм с двусторонней полировкой с использованием термокриометрической установки Linkam (THMSG 600), позволяющей в температурном интервале от -195 до $600^{\circ} \mathrm{C}$ реализовывать автоматический (программный) режим охлаждения/нагревания образца со скоростью от 0.1 до $90^{\circ} \mathrm{C} /$ мин. Стандартная аппаратурная ошибка измерений соответствовала $\pm 0.1^{\circ} \mathrm{C}$. Для расчета плотности и мольных объемов и флюидных включений использовалась программа FLUIDS (Bakker, Package, 2003). Изохоры рассчитывались по программе (Duan et al., 1996).

Таблица 1. Т-Р условия амфиболизации гранулита, определённые с помощью значений амфибол-плагиоклазового равновесия (Blundy, Holland, 1990).

Table 1. T-P conditions of granulite amphibolization process determined by means of amphibole-plagioclase equilibrium (Blundy, Holland, 1990).

\begin{tabular}{|c|l|l|l|l|l|l|l|}
\hline $\begin{array}{c}\text { Amph, №/ } \\
\text { компоненты }\end{array}$ & $24 Ц$ & $25 K$ & $27 Ц$ & $28 K$ & $35 K$ & $42 Ц$ & $43 К$ \\
\hline $\mathrm{SiO}_{2}$ & 42.49 & 42.16 & 42.99 & 42.38 & 43.44 & 43.26 & 42.86 \\
\hline $\mathrm{TiO}_{2}$ & 1.71 & 1.32 & 1.88 & 1.71 & 0.80 & 1.34 & 1.57 \\
\hline $\mathrm{Al}_{2} \mathrm{O}_{3}$ & 11.65 & 11.67 & 11.94 & 11.97 & 11.82 & 11.14 & 11.52 \\
\hline $\mathrm{FeO}$ & 20.59 & 20.34 & 20.37 & 20.98 & 19.67 & 19.90 & 20.81 \\
\hline $\mathrm{MgO}$ & 8.39 & 8.50 & 8.26 & 8.34 & 9.31 & 8.91 & 8.40 \\
\hline $\mathrm{MnO}$ & 0.38 & 0.28 & 0.35 & 0.13 & 0.33 & 0.31 & 0.29 \\
\hline $\mathrm{CaO}$ & 12.24 & 12.19 & 11.09 & 12.23 & 12.14 & 12.46 & 12.11 \\
\hline $\mathrm{Na} 2 \mathrm{O}$ & 1.47 & 1.35 & 1.44 & 1.14 & 1.16 & 1.56 & 1.21 \\
\hline $\mathrm{K}_{2} \mathrm{O}$ & 1.25 & 1.32 & 1.29 & 0.95 & 0.99 & 1.24 & 1.10 \\
\hline $\mathrm{F}$ & 0.00 & 0.00 & 0.00 & 0.00 & 0.00 & 0.00 & 0.00 \\
\hline$\underline{\mathrm{Cl}}$ & $\underline{0.00}$ & $\underline{0.00}$ & $\underline{0.00}$ & $\underline{0.00}$ & $\underline{0.00}$ & $\underline{0.00}$ & $\underline{0.00}$ \\
\hline $\mathrm{Cyмма}$ & 100.17 & 99.13 & 99.61 & 99.83 & 99.66 & 100.12 & 99.87 \\
\hline $\mathrm{Pl}$ & & & & & & & \\
\hline $\mathrm{xAb}$ & 0.53 & 0.53 & 0.53 & 0.53 & 0.53 & 0.53 & 0.53 \\
\hline $\mathrm{xAn}$ & 0.47 & 0.47 & 0.47 & 0.47 & 0.47 & 0.47 & 0.47 \\
\hline & & & & & & & \\
\hline $\mathrm{T},{ }^{\circ} \mathrm{C}$ & $\mathbf{7 6 6 . 3}$ & $\mathbf{7 5 6 . 0}$ & $\mathbf{7 7 9 . 9}$ & $\mathbf{7 6 2 . 9}$ & $\mathbf{7 4 5 . 6}$ & $\mathbf{7 3 9 . 9}$ & $\mathbf{7 6 0 . 4}$ \\
\hline $\mathrm{P}$, кбар & $\mathbf{5 . 0 0}$ & $\mathbf{5 . 3 3}$ & $\mathbf{4 . 8 6}$ & $\mathbf{5 . 2 9}$ & $\mathbf{5 . 5 1}$ & $\mathbf{5 . 1 9}$ & $\mathbf{5 . 0 3}$ \\
\hline
\end{tabular}

Флюидные включения были изучены в кварце и представлены углекислотными и водносолевыми разностями. Углекислотные включения относительно мелкие размером 5-15 мкм, реже встречаются до 20-25 мкм. По текстурным особенностям представлены только первичновторичными разностями (маркируют залеченные трещины в пределах отдельных зерен) (рис. 4). Температуры гомогенизации и соответственно плотности углекислотных включений варьируют от 4.2 до $8.1^{\circ} \mathrm{C}$ и от 0.901 до 0.875 г $/ \mathrm{cm}^{3}$. Температура плавления включений изменяется от $-57.1^{\circ} \mathrm{C}$ до $-59.8^{\circ} \mathrm{C}$.

Водно-солевые включения обычно плоские, светлые, удлиненно-овальные или неправильной формы, часто с оттянутыми концами размером, не превышающим 25 мкм. Локализуются во всех случаях вдоль залеченных трещин, не пересекающих границы отдельных зерен (первично-вторичные) (рис.5). Начальное плавление льда во включениях происходит в интервале от -58 до $-55^{\circ} \mathrm{C}$, что ука- 
зывает на присутствие в растворе $\mathrm{CaCl}_{2}$. Конечная температура плавления льда варьирует от $-16.7^{\circ} \mathrm{C}$ до $-13.1^{\circ} \mathrm{C}$, что соответствует содержанию $\mathrm{NaCl}$-эквивалента 17.09-20.19 мас. \%.

\section{Результаты}

Результаты новых Р-Т исследований, данных о флюидных включениях в этих породах подтвердили выводы исследователей (Сафонов и др., 2016, 2017). Образование плагиогранитных магм, вероятно, происходило на глубинах порядка 25-30 км. По мере подъема, они захватывали разнообразные ксенолиты (Козлов, Козлова, 1998). Амфибол-плагиоклазовое равновесие (Blundy, Holland, 1990) зафиксировало температуры процесса амфиболизации ксенолитов $740-780^{\circ} \mathrm{C}$ при давлении 5.0-5.5 кбар. Вариации состава амфибола в сторону снижения температуры. Он, вероятно, был связан со взаимодействием существенно водного флюида из остывающей плагиогранитной магмы с ксенолитами по мере их захвата и подъема. Действительно, ксенолиты пересечены жилами плагиогранитного состава (рис. 1 b).

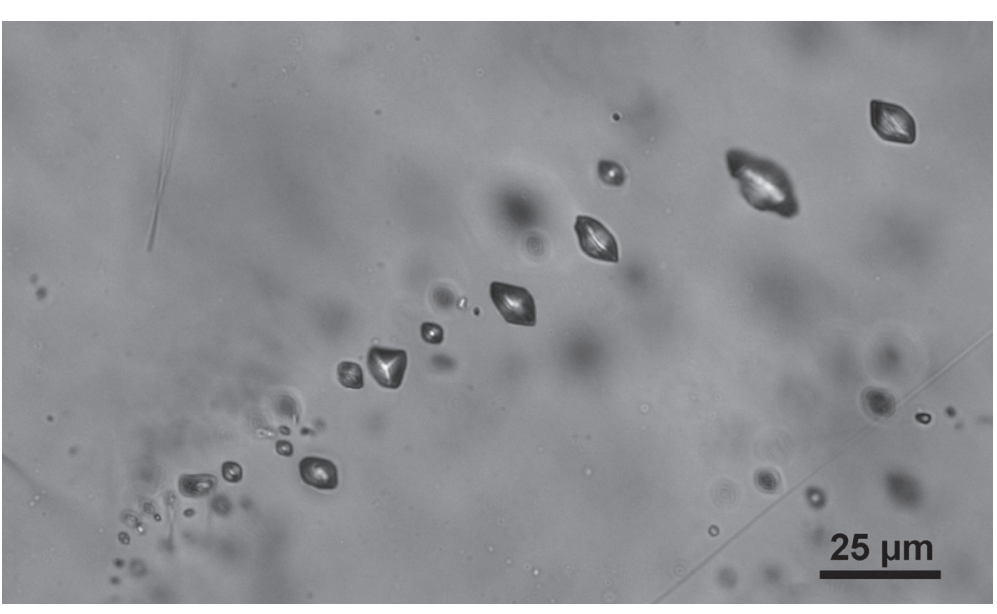

Рис. 4. Микрофотография первично-вторичных углекислотных включений в кварце.

Fig. 4. A photomicrograph of primary-secondary carbon dioxide inclusions in quartz.
Обилие водно-солевых (17-20 мас. \% $\mathrm{NaCl}$ эквивалента) включений и подчиненное количество углекислых включений в минералах плагиогранитов подтверждает это предположение (рис. 4, 5). Таким образом, плагиограниты Лапландского комплекса и ассоциирующиеся с ними флюиды формировались внутри самого комплекса при Р-Т параметрах, сопоставимых с условиями пика гранулитового метаморфизма комплекса. Поднимаясь на более высокие уровни в гранулитовом комплексе эти граниты могли производить лишь флюидные эффекты на вмещающие породы.
Рис. 5. Микрофотография первично-вторичных водно-солевых включений в кварце.

Fig. 5. A micrograph of primary secondary water-salt inclusions in quartz.

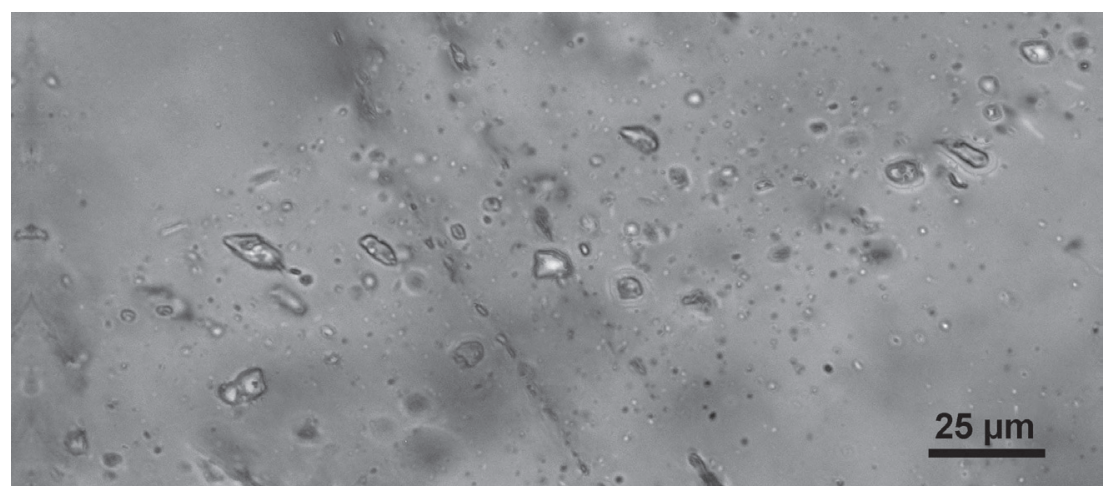

\section{Литература}

1. Каулина Т.В., Нерович Л.И., Баянова Т.Б., Япаскурт В.О. Последовательность геологических процессов в Центральной и Северо-Восточной части Лапландского гранулитового пояса: изотопно-геохимические данные по циркону и результаты геолого-петрологических исследований. Геохимия. 2014. № 7. С. 625-645.

2. Козлов Н.Е., Козлова Н.Е. О генезисе гранатовых плагиогранитоидов Лапландского гранулитового пояса. Вестник МГТУ. 1998. № 1. С. 43-52.

3. Сафонов О.Г., Реутский В.Н., Голунова М.А., Бутвина В.Г., Япаскурт В.О., Варламов Д.А. Различные источники углерода во флюидах гранитоидов в гранулитовых комплексах // XXI симпозиум по геохимии изотопов имени академика А.П. Виноградова. Москва. 15-17 ноября 2016. 
4. Сафонов О.Г., Реутский В.Н., Голунова М.А., Бутвина В.Г., Япаскурт В.О., Варламов Д.А., Щербаков В.Д., ван Bakker R.J. Package FLUIDS 1. Computer programs for analysis of fluid inclusion data and for modelling bulk fluid properties // Chem. Geol. 2003. V. 194. P. 3-23).

5. Berman R.G., 2007. WinTWQ (version 2.3): A software package for performing internally-consistent thermobarometric calculations. Geological Survey of Canada Open File 5462.

6. Blundy J.D., Holland T.J.B., 1990. Calcic amphibole equilibria and a new amphibole-plagioclase geothermometer. Contribution to Mineralogy and Petrology. V. 104, P. 208-224.

7. Duan Z., Møller N., Weare, J.H. A general equation of state for supercritical fluid mixtures and molecular dynamics simulation of mixture PVTX properties // Geochim. Cosmochim. Acta. 1996. V. 60. P. 1209-1216.

8. Glebovitsky V., Marker M., Alexejev N., Bridgwater D., Sedova I., Salnikova E., Berezhnaya N., Age, evolution and regional setting of the Palaeoproterozoic Umba igneous suite in the Kolvitsa-Umba zone, Kola Peninsula: Constrains from new geological, geochemical and U-Pb zircon data. Precambrian Research. V. 105. P. 247-267. 2001.

9. Marker M., Henkel H., Lee M.K. Combined gravity and magnetic modelling of the Tanaelv and Lapland Granulite

10. Mints M.V., Kaulina T.V., Konilov A.N., Krotov A.V., Stupak V.M., 2007. The thermal and geodynamic evolution of the Lapland granulite belt: Implications for thermal structure of the lower crust during granulitefacies metamorphism. Gondwana Research. V. 12. P. 252-267. 